\title{
Inhibition of Biological Activities of the Aerobactin Receptor Protein in Rough Strains of Escherichia coli by Polyclonal Antiserum Raised against Native Protein
}

\author{
By MARK ROBERTS, $\dagger$ KARL G. WOOLDRIDGE, HILARY GAVINE, \\ SUSI IRAVATI KUSWANDI AND PETER H. WILLIAMS* \\ Department of Genetics, University of Leicester, Leicester LE1 7RH, UK
}

(Received 23 January 1989; revised 26 May 1989; accepted 14 June 1989)

The aerobactin iron-uptake system of plasmid ColV-K30, genetically isolated from other plasmid determinants by molecular cloning, was sufficient to restore full virulence in a mouse peritonitis model to a clinical Escherichia coli isolate, D551 $\left(\mathrm{O}^{2}: \mathrm{H}^{-}\right)$, whose resident aerobactin-encoding ColV plasmid had been lost by curing. Antiserum was raised in rabbits against live $E$. coli $\mathrm{K} 12$ cells expressing the outer-membrane aerobactin receptor protein and absorbed with an isogenic strain lacking the receptor. This antiserum inhibited binding of aerobactin, cloacin DF13 and bacteriophage B74K to the native protein in whole E. coli K12 bacteria expressing the receptor, or in membranes prepared from such organisms. However, it did not react with the native receptor protein in several wild strains unless lipopolysaccharide was first removed by treatment with trichloroacetic acid, nor did it protect mice in experimental infections with strain D551. Antisera raised in rabbits against partially or fully denatured forms of the aerobactin receptor reacted only in assays involving denatured protein; they showed no inhibition of the biological activities of the native receptor.

\section{INTRODUCTION}

Uptake of iron by many bacterial species is initiated by interaction of ferric-siderophores with specific outer-membrane receptor proteins. Escherichia coli (O'Brien \& Gibson, 1970) and other members of the Enterobacteriaceae (Pollock et al., 1970; Perry \& San Clemente, 1979) synthesize the phenolic siderophore enterochelin (enterobactin), but some clinical isolates of enteric bacteria also possess a second high-affinity iron-uptake system mediated by the hydroxamate siderophore aerobactin (Braun, 1981; Warner et al., 1981; Roberts et al., 1986 b; Martinez et al., 1987). The ability to make and use aerobactin increased the virulence of $E$. coli K12 strains in experimental infections (Williams, 1979), and a number of epidemiological studies showed significantly higher incidence of the aerobactin system among bacteria isolated from extraintestinal infections than among isolates from the faeces of healthy individuals (Montgomerie et al., 1984; Carbonetti et al., 1986; Linggood et al., 1987; Jacobson et al., 1988).

The receptor for ferric-aerobactin in $E$. coli is an iron-regulated outer-membrane protein, IutA, which has an apparent molecular mass of $74000 \mathrm{Da}$ as determined by SDS-PAGE (Bindereif et al., 1982). However, the iut $A$ gene has been sequenced and its product is therefore known to have a molecular mass of $77345 \mathrm{Da}$ (Krone et al., 1985). Since the aerobactin system is considered to be an important virulence factor in extraintestinal infections, the possibility that IutA might elicit protective antibodies that could be used in immunoprophylactic therapy was investigated. The rationale has two aspects. First, specific binding of immunoglobulins to IutA may inhibit interaction with ferric-aerobactin. Blockage of ferripyochelin uptake by polyclonal

† Present address: Wellcome Biotechnology, Langley Park, Beckenham, Kent, UK. 
and monoclonal antibodies against the ferripyochelin-binding protein in Pseudomonas aeruginosa has previously been observed (Coulton, 1982; Sokol \& Woods, 1984, 1986) and Coulton (1982) reported reduction of ferrichrome binding to the $E$. coli FhuA protein by polyclonal sera raised against the receptor. Second, antibodies raised against IutA may lead to mediation of immune mechanisms by opsonization or activation of the complement cascade. In an attempt to evaluate the prospects of using the aerobactin receptor as a protective antigen, we raised antisera against both native and denatured forms and assessed their activity in a variety of assays involving either the denatured receptor or the biologically active native protein expressed by laboratory and clinical strains of $E$. coli.

\section{METHODS}

Bacterial strains and plasmids. Strain BZB1022 is a cir (colicin-I-resistant due to loss of the chromosome-encoded $70000 \mathrm{Da}$ outer-membrane protein, $\mathrm{Cir}$ ), gyrA (nalidixic-acid-resistant) derivative of the standard E. coli K12 strain W31 10 (Pugsley, 1985). Strain D551 is an aerobactin-producing $E$. coli ColV isolate $\left(\mathrm{O} 78: \mathrm{H}^{-}\right)$from a case of chicken septicaemia (from the collection of Unilever Research, Colworth House, Sharnbrook, UK); strain LG1695 is a plasmid-cured derivative of D551 ( $\mathrm{ColV}^{-}$, unable to make aerobactin) selected after prolonged growth in the presence of $1 \%(\mathrm{w} / \mathrm{v})$ SDS. E. coli strains of serotypes $04: \mathrm{K} 12, \mathrm{O}: \mathrm{K} 2,018 \mathrm{ac}: \mathrm{K} 5$ and $075: \mathrm{K} 5$ are representatives of some of the major clonal groups associated with human urinary-tract infections (VäisänenRhen et al., 1984); strains of serotypes $07: \mathrm{K} 1$ and $\mathrm{O}^{-}: \mathrm{K} 1$ were from cases of septicaemia in infants less than 21d-old (Korhonen et al., 1985). Klebsiella pneumoniae strain M5al expresses a receptor protein for type 1 klebicins [of which cloacin DF13 is an example (Cooper \& James, 1985)] and for aerobactin, but does not itself make the siderophore.

Recombinant plasmid pABN1 contains a $16.3 \mathrm{~kb}$ HindIII fragment of the prototype plasmid ColV-K30 which expresses the complete aerobactin system in an iron-regulated fashion (Bindereif \& Neilands, 1983). Plasmid pLG141 contains a $6.5 \mathrm{~kb}$ BamHI fragment of pABN1 which expresses the aerobactin receptor (IutA) constitutively, but lacks most of the genetic determinants of aerobactin biosynthesis (Carbonetti \& Williams, 1984).

Conjugation by standard methods was used to introduce the derepressed $\mathrm{tra}^{+}$plasmid ColV-K 30 from strain KH576 (Williams, 1979) into strain LG1695. The method of Cohen et al. (1972) was used to transform competent E. coli K12 or LG1695 bacteria with purified recombinant-plasmid DNA.

Culture media. Bacteria were grown in either nutrient broth (Oxoid no. 2) or M9 minimal salts medium (Roberts et al., 1963) containing $0.2 \%(\mathrm{w} / \mathrm{v})$ glucose, $0.5 \%(\mathrm{w} / \mathrm{v})$ Casamino acids and $20 \mu \mathrm{g}$ tryptophan $\mathrm{ml}^{-1}$. Ampicillin $\left(100 \mu \mathrm{g} \mathrm{ml}^{-1}\right)$ or chloramphenicol $\left(10 \mu \mathrm{g} \mathrm{ml}^{-1}\right)$ were included in media for the growth of strains carrying recombinant plasmids pABN1 or pLG141 respectively. $\alpha, \alpha^{\prime}$-Dipyridyl $(200 \mu \mathrm{M}$; Sigma), $0.31 \mathrm{mg}$ desferrioxamine $\mathrm{ml}^{-1}$ (Desferal, Ciba-Geigy) or $2.5 \mathrm{mg}$ human transferrin $\mathrm{l}^{-1}$ (Sigma) were added as required to limit availability of iron. Solid media contained $1.5 \%$ (w/v) agar (Difco).

Experimental infections. Groups of five BALB/C mice of about $20 \mathrm{~g}$ body weight were inoculated intraperitoneally with $0.5 \mathrm{ml}$ of an appropriate dilution of the infecting strain grown overnight in nutrient broth. Mice were examined regularly for death and any that survived after $48 \mathrm{~h}$ were sacrificed.

Antisera. Strain BZB1022(pABN1) was chosen as the vaccinating strain to raise antiserum against native aerobactin receptor because it lacks the similarly sized Cir protein (Pugsley, 1985). Bacteria were grown overnight in M9 medium containing dipyridyl and ampicillin. Rabbits were given five intravenous inoculations at 5-d intervals with $0 \cdot 1,0.2,0.4,1.0$ and $1.5 \mathrm{ml}$ of bacteria harvested by centrifugation at $2000 \mathrm{~g}$ and resuspended in the same volume of PBS (140 mM-NaCl, $27 \mathrm{mM}-\mathrm{KCl}, 1.5 \mathrm{~mm}-\mathrm{KH}_{2} \mathrm{PO}_{4}, 8 \mathrm{mM}-\mathrm{Na}_{2} \mathrm{HPO}_{4}$ ), and bled $7 \mathrm{~d}$ after the last inoculation. For antisera against denatured receptor, membrane-protein samples [1 $\mathrm{mg}$ of solubilized membrane protein or $500 \mu \mathrm{g}$ of IutA (purified by SDS-PAGE) per inoculation] prepared as described below were mixed with an equal volume of Freund's complete adjuvant for primary inoculations, and with Freund's incomplete adjuvant for subsequent inoculations, and administered subcutaneously at six sites on the backs of the rabbits. Secondary inoculations were given after a 1 month interval, and rabbits were bled $14 \mathrm{~d}$ later.

Preparation of outer-membrane-protein antigens. Strain BZB1022(pABN1) was grown overnight in $250 \mathrm{ml}$ of M9 medium containing dipyridyl at $37^{\circ} \mathrm{C}$ with aeration by shaking. Bacteria were harvested by centrifugation at $10000 \mathrm{~g}$ for $10 \mathrm{~min}$ at room temperature, resuspended in $10 \mathrm{ml} 100 \mathrm{mM}-\mathrm{Tris} / \mathrm{HCl}(\mathrm{pH} 7.8), 10 \mathrm{mM}-\mathrm{MgCl}_{2}$, and disrupted by sonication. Non-disrupted cells were removed by centrifugation at $9000 \mathrm{~g}$ for $10 \mathrm{~min}$ at $4^{\circ} \mathrm{C}$, and the supernatant fraction was subjected to centrifugation at $100000 \mathrm{~g}$ for $40 \mathrm{~min}$ at $4{ }^{\circ} \mathrm{C}$. Pellets containing the total membrane fraction were resuspended in $1 \mathrm{ml}$ of the Tris/ $\mathrm{MgCl}_{2}$ buffer containing $2 \%(\mathrm{v} / \mathrm{v})$ Triton X-100 to dissolve inner membrane proteins and again subjected to centrifugation at $100000 \mathrm{~g}$ for $40 \mathrm{~min}$ at $4{ }^{\circ} \mathrm{C}$. Pellets containing outer membranes were resuspended as before, incubated at room temperature for $30 \mathrm{~min}$ and again subjected to centrifugation at $100000 \mathrm{~g}$ for $90 \mathrm{~min}$ at $4^{\circ} \mathrm{C}$. Soluble outer-membrane-protein preparations for 
inoculation of rabbits were prepared by resuspending and homogenizing the final pellets in $50 \mathrm{~mm}$-sodium phosphate buffer (pH 7.2) containing 4 mM-EDTA, $2 \%$ (w/v) Triton X-100 and $1.5 \mathrm{M}$-urea. Remaining insoluble material was pelleted by ultracentrifugation as described above, and supernatant fractions were extensively dialysed against the sodium phosphate/EDTA/Triton X-100 buffer to remove the urea before inoculation into a rabbit. Denatured IutA protein was prepared by mixing outer membrane protein samples with an equal volume of $0.25 \mathrm{M}$-Tris $/ \mathrm{HCl}(\mathrm{pH} 8.8)$ containing $2 \%(\mathrm{w} / \mathrm{v})$ SDS, $10 \%(\mathrm{v} / \mathrm{v})$ glycerol and $5 \%(\mathrm{v} / \mathrm{v})$ 2-mercaptoethanol, incubating at $65^{\circ} \mathrm{C}$ for $30 \mathrm{~min}$ and loading onto a preparative $11 \%(\mathrm{w} / \mathrm{v}$, acrylamide) SDS-polyacrylamide gel for electrophoresis to separate the constituent polypeptides. The gel was briefly stained with Coomassie blue and then destained; a gel slice containing the IutA protein was excised, soaked in water for $30 \mathrm{~min}$ and then macerated. A small volume of PBS was added before inoculation into a rabbit.

Immunoblotting. Suspensions of outer-membrane preparations were boiled for $5 \mathrm{~min}$ in the presence of $1 \%(\mathrm{w} / \mathrm{v})$ SDS, separated by electrophoresis in $11 \%$ SDS-polyacrylamide gels, and electroblotted onto nitrocellulose paper (Hybond C, Amersham) by the method of Towbin et al. (1979). Filters were soaked overnight at $4{ }^{\circ} \mathrm{C}$ in PBS containing $0.05 \%(\mathrm{v} / \mathrm{v})$ Tween 20 , incubated with primary antiserum appropriately diluted in PBS/Tween for $30 \mathrm{~min}$ at room temperature and then washed thoroughly with PBS/Tween. Filters were then incubated with secondary antiserum (Dakopatts, Denmark; swine immunoglobulins to rabbit immunoglobulins) diluted 1:800 in PBS/Tween for $30 \mathrm{~min}$ at room temperature, washed thoroughly, and incubated with a soluble complex of horseradish peroxidase and rabbit anti-horseradish peroxidase (Dakopatts) diluted 1:800 in PBS/Tween for $30 \mathrm{~min}$ at room temperature. After further thorough washing, the filters were stained for $2 \mathrm{~min}$ in $30 \mathrm{mg} 4$-chloro1-naphthol in $20 \mathrm{ml}$ methanol to which $50 \mathrm{ml} 50 \mathrm{mM}$-Tris/ $\mathrm{HCl}(\mathrm{pH} 7.6)$ and $100 \mu 130 \%(\mathrm{v} / \mathrm{v}) \mathrm{H}_{2} \mathrm{O}_{2}$ had been added immediately before use, and then rinsed with water and air dried.

Radioimmunoprecipitation. Strain BZB1022(pABN1) was grown at $37^{\circ} \mathrm{C}$ in $\mathrm{M} 9$ medium containing desferrioxamine to the mid-exponential phase of growth with aeration by shaking. Samples $(0.5 \mathrm{ml})$ of culture were incubated with $555 \mathrm{kBq}\left[{ }^{35}\right.$ S] methionine (Amersham; $46 \mathrm{TBq} \mathrm{mmol}{ }^{-1}$ ) for $5 \mathrm{~min}$, after which labelled bacteria were collected by centrifugation at $10000 \mathrm{~g}$ for $5 \mathrm{~min}$, washed with ice-cold $10 \mathrm{mM}-\mathrm{Tris} / \mathrm{HCl}(\mathrm{pH} 8 \cdot 0)$, and suspended in $0.5 \mathrm{ml}$ of the same buffer containing $1 \%(\mathrm{w} / \mathrm{v})$ SDS and $1 \mathrm{mM}$-EDTA. Samples were boiled for $2 \mathrm{~min}$, and diluted to $0.7 \mathrm{ml}$ with $50 \mathrm{~mm}-\mathrm{Tris} / \mathrm{HCl}(\mathrm{pH} 8 \cdot 0)$ containing $2 \%(\mathrm{v} / \mathrm{v})$ Triton $\mathrm{X}-100,150 \mathrm{mM}-\mathrm{NaCl}$ and $1 \mathrm{mM}-$ EDTA; cell debris was then removed by centrifugation at $10000 \mathrm{~g}$ for $5 \mathrm{~min}$. Supernatant fractions were incubated overnight at $4{ }^{\circ} \mathrm{C}$ with antiserum samples $(2-10 \mu \mathrm{l})$. Staphylococcus aureus cells $(10 \mu \mathrm{l}$ of a $10 \%$, w/v, suspension, prepared essentially as described by Kessler, 1975) were added to the cell lysate/antibody mixtures and incubated for $30 \mathrm{~min}$ on ice. The samples were again boiled, cell debris was pelleted by centrifugation and the supernatants were analysed by SDS-PAGE and subsequent autoradiography.

Enzyme-linked immunosorbant assay (ELISA). Antisera were diluted 1:50 in PBS and absorbed three times for $1 \mathrm{~h}$ at room temperature and with continuous mixing with $2 \%(\mathrm{w} / \mathrm{v})$ suspensions of cells of appropriate strains grown overnight in M9 medium containing dipyridyl. Cells for sensitizing ELISA plates were harvested by centrifugation at $12000 \mathrm{~g}$ for $5 \mathrm{~min}$ from overnight $\mathrm{M} 9$ cultures containing dipyridyl, washed, and resuspended in

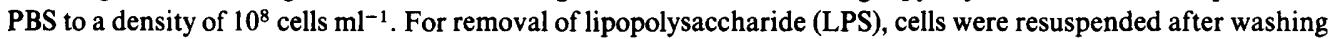
in $20 \mathrm{ml} 1 \%(\mathrm{w} / \mathrm{v})$ trichloroacetic acid (TCA) in $0 \cdot 14 \mathrm{M}-\mathrm{NaCl}$, and incubated at $4{ }^{\circ} \mathrm{C}$ for $1 \mathrm{~h}$ with continuous agitation before being pelleted by centrifugation at $2000 \mathrm{~g}$ for $10 \mathrm{~min}$ and washed again as described above. Cell suspensions $\left(50 \mu \mathrm{l}\right.$ per well) were used to coat ELISA plates (Dynatech Microelisa) overnight at $4{ }^{\circ} \mathrm{C}$. Liquid was removed and replaced by PBS containing $10 \%(\mathrm{v} / \mathrm{v})$ foetal calf serum and $0.5 \%(\mathrm{w} / \mathrm{v})$ casein, and the plates were incubated at room temperature for $2 \mathrm{~h}$ before being washed three times with PBS containing $0.05 \%(\mathrm{v} / \mathrm{v})$ Tween 20. Absorbed antisera were diluted in PBS containing foetal calf serum and casein, and applied to appropriate ELISA plates at $50 \mu \mathrm{l}$ per well. Plates were incubated at $37^{\circ} \mathrm{C}$ for $30 \mathrm{~min}$, washed, and then secondary antiserum (Dakopatts; goat immunoglobulins to rabbit immunoglobulins conjugated with horseradish peroxidase) diluted 1:1000 in PBS/Tween was applied and incubated as described above. Plates were washed with

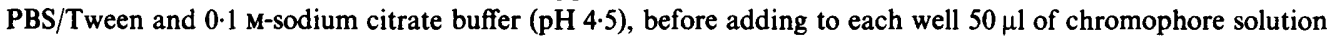
( $1 \mu \mathrm{g} o$-phenylenediamine dihydrochloride $\mathrm{ml}^{-1}$ in $0.1 \mathrm{M}$-citrate buffer, $\mathrm{pH} 4.5$, to which $0.4 \mu \mathrm{l} 30 \%, \mathrm{v} / \mathrm{v}, \mathrm{H}_{2} \mathrm{O}_{2}$ $\mathrm{mi}^{-1}$ had been added immediately before use). The colour that developed within a few min. was quantified by measuring the absorbance at $450 \mathrm{~nm}$ with a Tetertech Multiskan Plus ${ }^{\mathrm{TM}}$ ELISA reader (Flow Laboratories).

Cloacin-DF13-binding assay. Cloacin DF13 was prepared by mitomycin-C-induction of a producing strain, essentially as described by de Graaf et al. (1969). To assess the effect of antisera on cloacin DF13 binding to receptors, insoluble outer-membrane preparations of BZB1022(pABN1) were incubated at $37^{\circ} \mathrm{C}$ for $1 \mathrm{~h}$ and then at $4{ }^{\circ} \mathrm{C}$ overnight with an equal volume of either PBS alone or antiserum appropriately diluted in PBS. The membranes were recovered by centrifugation at $100000 \mathrm{~g}$ for $40 \mathrm{~min}$ at $4{ }^{\circ} \mathrm{C}$ and resuspended to the original volume in buffer containing $2 \%(\mathrm{w} / \mathrm{v})$ Triton X-100. Samples $(15 \mu \mathrm{l})$ of suspension were added to $2 \mathrm{ml}$ of nutrient broth containing serial dilutions of cloacin DF13, and incubated at $37^{\circ} \mathrm{C}$ for $1 \mathrm{~h}$. Samples $(0.5 \mathrm{ml})$ of an exponential-phase nutrient broth culture of indicator strain M5al were added to each mixture and incubated with agitation at $37^{\circ} \mathrm{C}$ for $4 \mathrm{~h}$, after which cell growth was determined by measurement of the optical density at $600 \mathrm{~nm}$. 
Aerobactin-binding assay. $\left[{ }^{14} \mathrm{C}\right]$ Aerobactin was prepared by the method of Ford et al. (1986). To assess the effect of antisera on aerobactin binding to receptors, cells from $5 \mathrm{ml}$ of overnight nutrient broth cultures of W3110, W3110(pLG141) or D551 were harvested by centrifugation at $2000 \mathrm{~g}$ for $10 \mathrm{~min}$, washed in PBS and resuspended in either antiserum (heated to $56^{\circ} \mathrm{C}$ for $30 \mathrm{~min}$ to destroy complement activity) appropriately diluted in PBS, cloacin DF13 in PBS, or PBS alone. Mixtures were incubated at room temperature with continuous agitation for $30 \mathrm{~min}$. Cells were recovered by centrifugation at $10000 \mathrm{~g}$ for $10 \mathrm{~min}$, washed twice and resuspended in one-tenth the original volume of PBS. $\left[{ }^{14} \mathrm{C}\right]$ Ferriaerobactin $(1 \mu \mathrm{l}$; approximately 1500 c.p.m., corresponding to 1 pmol aerobactin) was added to each sample, and incubation was continued for a further $30 \mathrm{~min}$. The cells were harvested by centrifugation at $10000 \mathrm{~g}$ for $10 \mathrm{~min}$, and the radioactivity associated with pellet and supernatant fractions was determined by liquid scintillation counting in $2 \mathrm{ml}$ vols of Packard Emulsifier Safe fluid in a Packard Tri-Star liquid scintillation spectrometer.

Bacteriophage-binding assay. Bacteriophage B74K, recently isolated in our laboratory from crude sewage, forms plaques on $E$. coli $\mathrm{K} 12$ strains expressing the $74000 \mathrm{Da}$ aerobactin receptor (i.e. harbouring plasmids ColV-K 30 , pABN1 or pLG141) but only poorly on Iut $^{-}$strains. To assess the effect of antisera on the binding of phage to the native receptor, cells from $1.5 \mathrm{ml}$ of overnight nutrient broth culture of W3110 or W3110(pLG141) were harvested by centrifugation $(10000 \mathrm{~g}, 5 \mathrm{~min})$, washed in PBS, resuspended in either antiserum appropriately diluted in PBS, or PBS alone, and incubated at $37^{\circ} \mathrm{C}$ for $15 \mathrm{~min}$. Phage $\left(10^{5}\right.$ p.f.u. in $\left.0.1 \mathrm{ml}\right)$ were added to each suspension and incubated at $37^{\circ} \mathrm{C}$ for $15 \mathrm{~min}$. The cells were pelleted by centrifugation $(10000 \mathrm{~g}, 5 \mathrm{~min})$ and the chloroformsterilized supernatant fractions were titrated in standard plaque assays with W3110(pLG141) as the indicator lawn.

\section{RESULTS}

\section{Importance of the aerobactin system in extraintestinal infections}

Although both epidemiological evidence and infection studies with strains harbouring ColV plasmids indicate that the aerobactin system is an important virulence determinant in $E$. coli (Montgomerie et al., 1984; Carbonetti et al., 1986; Linggood et al., 1987; Jacobson et al., 1988) it should be noted that other genes carried on ColV plasmids might also be involved in the observed enhancement of virulence associated with these plasmids (Binns et al., 1979; Clancy \& Savage, 1981). Moreover, experimental infection studies have usually employed $E$. coli $\mathrm{K} 12$ strains which are severely enfeebled with respect to host-defence mechanisms, and mutants generated by $N$-methyl- $N^{\prime}$-nitro- $N$-nitrosoguanidine which may produce multiple mutations (Williams, 1979). In this study a ColV ${ }^{+} \mathrm{O} 78: \mathrm{H}^{-}$clinical isolate of $E$. coli, strain D551, was used to assess the influence of the aerobactin system alone on overall virulence in a murine peritonitis model. Curing D551 of its ColV plasmid reduced virulence at least 10-fold in this model (Table 1); however, introduction of the prototype plasmid ColV-K30 into the cured derivative (strain LG1695) by conjugation restored virulence. A transformant of strain LG1695 carrying only the aerobactin system of ColV-K30 expressed on the small recombinant plasmid pABN1 was slightly more virulent than the original clinical isolate. This may be due to the high copy number of pABN1 compared to ColV plasmids; not only might a higher gene dosage permit the synthesis of greater amounts of aerobactin and IutA under iron restriction, but low-level background expression of the aerobactin system prior to inoculation may allow the strain grown in nutrient broth to commence growth in vivo more quickly. Certainly, laboratory strains of $E$. coli harbouring pABN1 express the aerobactin system constitutively at a low level in vitro during growth in iron-rich media, presumably due to titration of the Fur repressor protein by multiple copies of the Fur binding site (Roberts et al., 1986a). Moreover, growth of D551 in ironrestricted conditions imposed by addition of transferrin to the medium significantly enhanced the virulence of the strain. Not only were more mice killed at any given dose, but the onset of death was faster with iron-starved bacteria than with bacteria grown in iron-rich media (Table 1). These results showed that the aerobactin determinants alone are sufficient to account for the virulence-enhancing properties of the ColV-K30 plasmid.

\section{Activity of antisera against denatured Iut $A$}

Antiserum raised against IutA $^{+}$bacteria showed no detectable activity against IutA in immunoblots; on the other hand, electroblotted IutA reacted with antiserum raised against Triton/urea-solubilized outer-membrane proteins derived from an IutA ${ }^{+}$strain (Fig. 1a). Both 
(a)

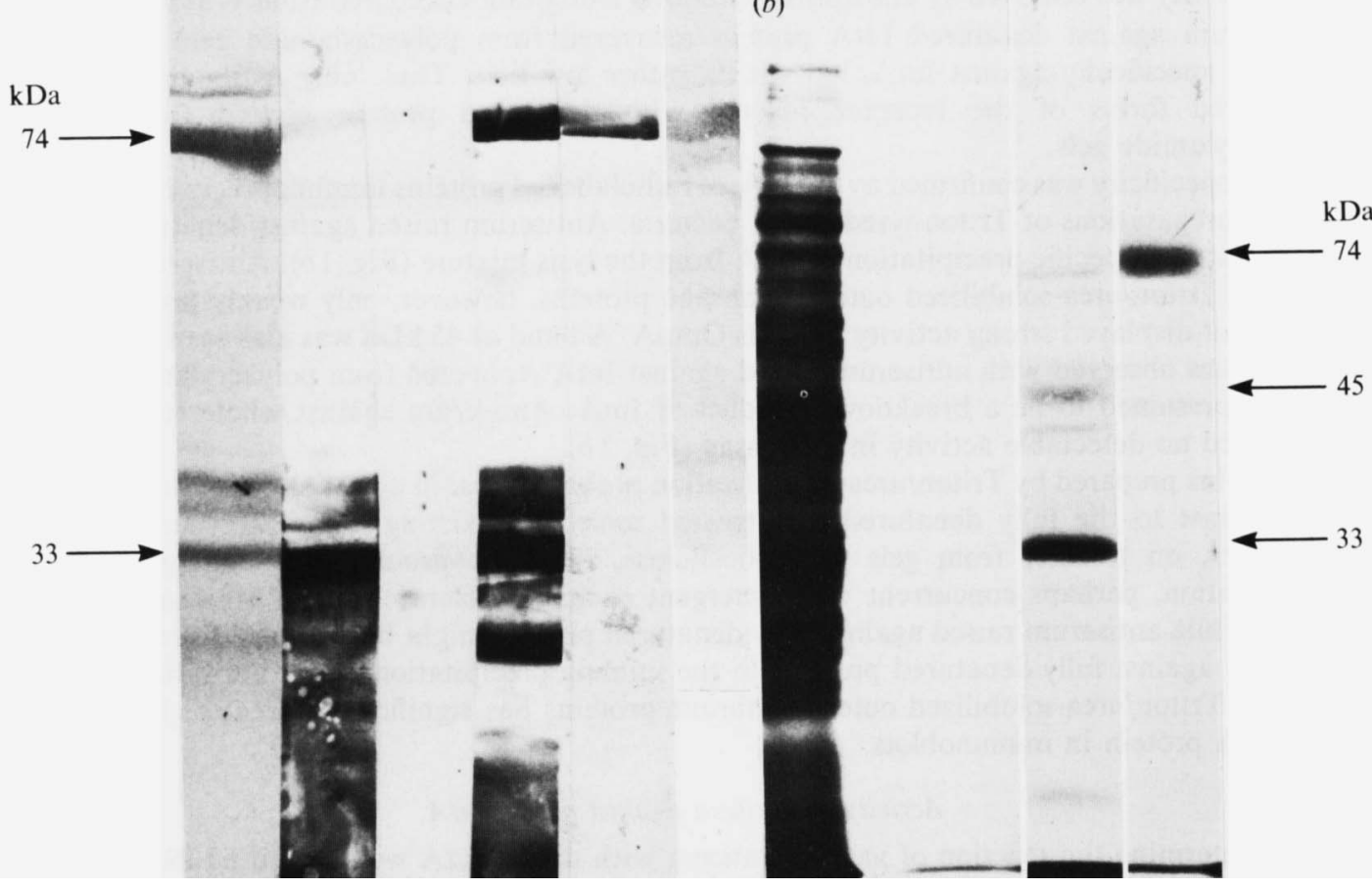

Fig. 1. Activity of antisera against IutA in assays involving denatured proteins. (a) Immunoblotting of outer-membrane proteins of strain BZB1022(pABN1). Lane 1, amido-black-stained strip of nitrocellulose showing effective transfer of proteins. Lanes 2 and 3, immunoblots with antiserum raised against whole cells of BZB1022(pABN1); lanes 4 and 5, immunoblots with antiserum raised against Triton/urea-soluble outer membranes of the same strain. For lanes 3 and 5 the antisera were absorbed twice with a membrane preparation of strain W3110 before use. Both antisera were diluted 1:800. Lane 6, immunoblot with antiserum (diluted 1:300) raised against gel-purified IutA protein. (b) Autoradiograph of radiolabelled BZB1022(pABN1) proteins immunoprecipitated by various antisera, and analysed by electrophoresis. Lane 1 shows the total cell lysate from which proteins were precipitated by antisera against whole cells of BZB1022(pABN1) (lane 2), against Triton/ureasolubilized outer-membrane proteins of strain BZB1022(pABN1) (lane 3), or against gel-purified IutA protein (lane 4). Molecular masses (kDa) of the proteins mentioned in the text are indicated.

Table 1. Experimental infections of mice

\begin{tabular}{|c|c|c|c|c|c|c|c|}
\hline & & & & rtalit & & & \\
\hline & & & $0^{-7}$ & ose ( & 1.): $: \dagger$ & & \\
\hline strain & 0.5 & $1 \cdot 0$ & $2 \cdot 0$ & $4 \cdot 0$ & 10 & 20 & 40 \\
\hline D551 & - & 1 & 2 & 5 & - & - & - \\
\hline D551 (iron-starved) $\ddagger$ & 5 & 5 & 5 & - & - & - & - \\
\hline LG1695 & - & - & 0 & 0 & 1 & 2 & 4 \\
\hline LG1695(ColV-K30) & - & $\mathbf{0}$ & 1 & 4 & - & - & - \\
\hline LG1695(pABN1) & 1 & 2 & 5 & - & - & - & - \\
\hline
\end{tabular}

-, Not done.

* Number of mice from a group of 5 dead within $48 \mathrm{~h}$ postinoculation.

+ Groups of 5 BALB/C mice were inoculated with the numbers of bacteria indicated.

$\ddagger$ Strain grown in nutrient broth containing transferrin; all mice inoculated with these bacteria died within $18 \mathrm{~h}$. 
sera reacted with several smaller proteins, including a $33 \mathrm{kDa}$ protein identified as OmpA by the use of specific anti-OmpA antibodies in parallel precipitation experiments (data not shown). This activity was removed by absorption with total membranes prepared from W3110 (IutA ${ }^{-}$). Antiserum against denatured IutA protein recovered from polyacrylamide gels displayed activity specifically against IutA, but with a rather low titre. Thus, only antibodies against denatured forms of the receptor reacted with denatured protein blotted from SDSpolyacrylamide gels.

This specificity was confirmed by analysis of radiolabelled proteins immunoprecipitated from boiled preparations of Triton-lysed Iut $\mathrm{A}^{+}$bacteria. Antiserum raised against denatured IutA caused strong specific precipitation of IutA from the lysis mixture (Fig. 1b). Antiserum raised against Triton/urea-solubilized outer membrane proteins, however, only weakly precipitated IutA, but displayed strong activity towards OmpA. A band at $45 \mathrm{kDa}$ was also seen; this was sometimes observed with antiserum raised against IutA recovered from polyacrylamide gels, and is presumed to be a breakdown product of IutA. Antiserum against whole IutA ${ }^{+}$cells displayed no detectable activity in this assay (Fig. $1 b$ ).

Proteins prepared by Triton/urea-solubilization probably exist in a partially denatured form, in contrast to the fully denatured SDS-treated molecules existing in polyacrylamide gels. However, on transfer from gels to nitrocellulose, the IutA protein may undergo partial renaturation, perhaps concurrent with detergent exchange (Henrickson \& Maeland, 1987). Thus, while antiserum raised against fully denatured protein might be expected to react more strongly against fully denatured proteins in the immunoprecipitation assay, antiserum raised against Triton/urea-solubilized outer-membrane proteins has significantly greater affinity for the IutA protein in immunoblots.

\section{Activity of antisera against native IutA}

To determine the reaction of various antisera with native IutA we used an ELISA system based on whole cells expressing IutA as antigen. Antiserum raised against whole bacteria expressing the IutA protein was active in the ELISA with strain BZB1022 carrying pABN1 but not with the plasmid-free strain, indicating specific interaction with native receptor (Fig. $2 a$ ). Antiserum raised against IutA protein recovered from denaturing gels displayed a similar profile with a rather lower titre, but antiserum raised against Triton/urea-solubilized outermembrane proteins showed no activity specifically against the pABN1-containing strain.

\section{Effect of LPS on antibody binding to IutA}

None of the antisera, including that raised against whole Iut $^{+}$cells, gave a significant reaction in an ELISA with the clinical isolate D551 (Fig. 2b). To determine if this was due to blockage of antibody access, cells were treated with TCA to remove LPS. After TCA treatment, D551 cells gave a positive reaction with antiserum raised against whole bacteria, while TCAtreated LG1695, the ColV-plasmid-cured derivative of D551, did not (Fig. 2b). Similar results were obtained with a number of other aerobactin-producing clinical isolates of $E$. coli from human infections (data not shown); immunoglobulin binding to strains of serotypes $01: \mathrm{K} 1$, $\mathrm{O} 4: \mathrm{K} 12, \mathrm{O} 6: \mathrm{K} 2, \mathrm{O} 7: \mathrm{K} 5, \mathrm{O} 18 \mathrm{ac}: \mathrm{K} 5$ and $\mathrm{O} 75: \mathrm{K} 5$ was only observed after TCA treatment of the bacteria, although the enhancement was variable from serotype to serotype. Significant reaction of antiserum was observed in an ELISA with a rough clinical isolate of serotype $\mathrm{O}^{-}: \mathrm{K} 1$; in this case TCA treatment caused a slight reduction in the level of immunoglobulin binding.

\section{Inhibition of biological activities of Iut $A$}

We determined whether the activity of the antisera would interfere with three measurable biological functions of the receptor. Only antiserum raised against whole IutA ${ }^{+}$cells had a significant inhibitory effect on the binding of $\left[{ }^{14} \mathrm{C}\right]$ aerobactin to whole bacteria expressing the receptor (Table 2). Siderophore binding to strain W3110(pLG141) was reduced by approximately $40 \%$ when the cells were pre-treated with antiserum; similar results were observed with both $1: 2$ and $1: 10$ dilutions of antiserum suggesting that this was the maximum 


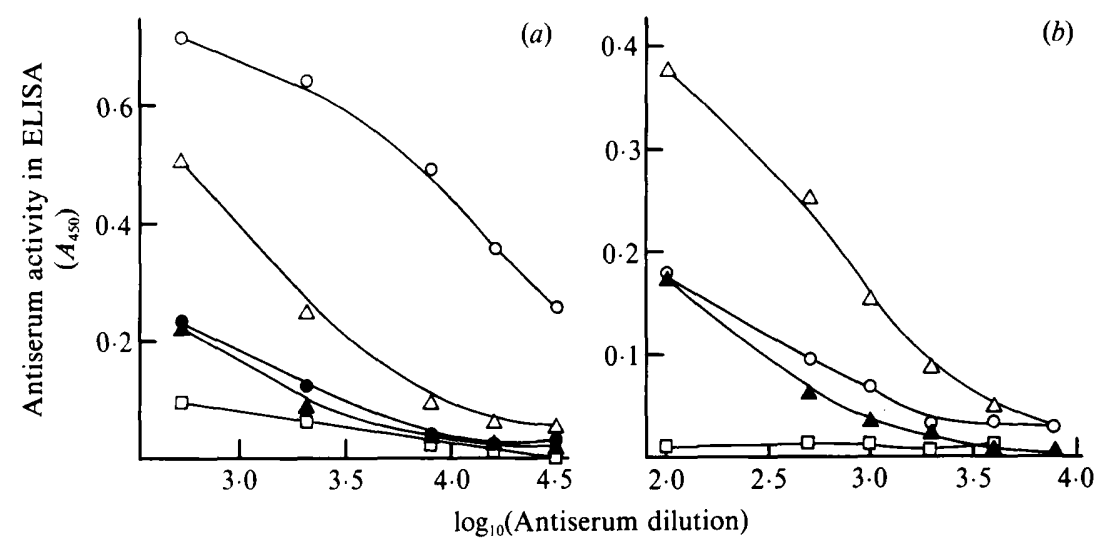

Fig. 2. Activity of antiserum against native IutA in ELISA. (a) Microtiter plates were coated with whole bacteria of strain BZB1022(pABN1) (open symbols) or BZB1022 (filled symbols) and reacted with dilution series of antiserum against whole Iut $A^{+}$bacteria $(O, \bullet)$, or of antiserum against denatured IutA protein $(\Delta, \boldsymbol{\Delta})$, or of pre-immune serum $(\square)$, (b) Dilutions of antiserum against whole Iut $A^{+}$ bacteria were added to wells of Microtiter plates coated with whole bacteria of strain D551, untreated $(O)$ or treated with TCA to remove LPS $(\triangle)$, or with whole TCA-treated bacteria of strain LG1695 $(\Delta)$. Plates coated with TCA-treated D551 were also reacted with dilutions of pre-immune serum ( $\square$ ). $A_{450}$ measurements were recorded after processing of plates as described in Methods. The effect of each treatment was determined four times; $1 \mathrm{SD}$ was always less than $0.05 A_{450}$ units.

Table 2. Effect of antisera and cloacin DF 13 on $\left[{ }^{14}\right.$ C]aerobactin binding to whole bacteria expressing the aerobactin receptor

\begin{tabular}{llr}
$\begin{array}{c}\text { Bacterial } \\
\text { strain }\end{array}$ & \multicolumn{1}{c}{ Pretreatment* } & $\begin{array}{c}\left.{ }^{14} \mathrm{C}\right] \text { Aerobactin } \\
\text { binding }\end{array}$ \\
W3110 & - & $8.0 \%$ \\
W3110(pLG141) & - & $100.0 \%$ \\
W3110(pLG141) & Pre-immune serum & $97.2 \%$ \\
W3110(pLG141) & Anti-whole cell serum & $59 \cdot 7 \%$ \\
W3110(pLG141) & Cloacin DF13 & $27.0 \%$ \\
D551 & - & $100.0 \%$ \\
D551 & Pre-immune serum & $75.3 \%$ \\
D551 & Anti-whole cell serum & $84.0 \%$ \\
D551 & Cloacin DF13 & $100.0 \%$
\end{tabular}

\footnotetext{
* Bacteria were incubated with the competitors indicated before addition of $\left[{ }^{14} \mathrm{C}\right]$ aerobactin.

$\dagger$ Binding is expressed as a percentage of the activity associated with each Iut $\mathrm{A}^{+}$strain in the absence of pretreatment [563 c.p.m. or 540 c.p.m. for strains W3110(pLG141) and D551, respectively].
}

inhibition achievable. The Enterobacter cloacae bacteriocin cloacin DF13, which also binds to aerobactin receptor proteins (de Graaf et al., 1969; Bindereif et al., 1982; Carbonetti \& Williams, 1984), reduced siderophore binding to W3110(pLG141) by more than $70 \%$. However, neither cloacin DF13 nor any of the antisera raised against IutA displayed significant inhibition of aerobactin binding to D551 cells.

Cloacin DF13 inhibits the growth of cultures of sensitive bacteria. As cloacin DF13 preparations are diluted, a level is reached at which inhibitory activity is lost, and cloacin DF13 binding can therefore be quantified as the dilution giving $50 \%$ inhibition of test-culture growth (de Graaf et al., 1969). Fig. 3 shows a representative experiment in which 14 doubling dilutions of a cloacin DF13 preparation were required for $50 \%$ inhibition of the growth of M5al cells, used because of their pronounced susceptibility to cloacin DF13. Addition of membranes prepared from a strain harbouring pABN1 consistently increased the level of cloacin DF13 required for $50 \%$ inhibition by approximately 10 -fold, but prior incubation of these membranes with antiserum raised against whole Iut $\mathrm{A}^{+}$cells abolished the protective effect. Pre-immune serum and the antisera raised against either outer-membrane fractions or purified IutA protein 


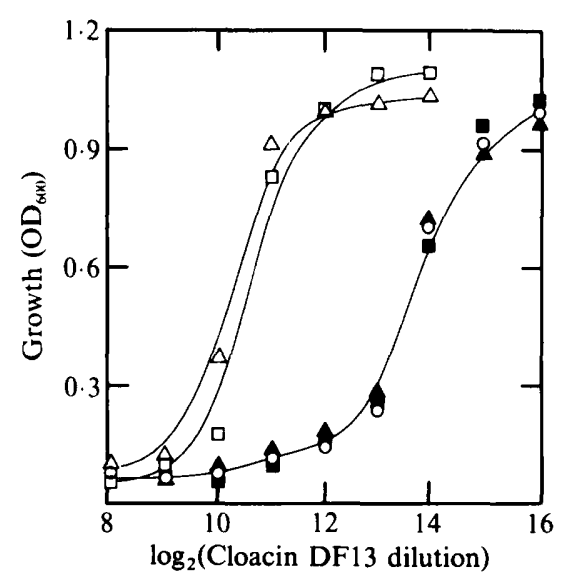

Fig. 3. Activity of antiserum against native IutA in the cloacin-DF13-binding assay. Growth of the indicator strain M5al was monitored (culture $\mathrm{OD}_{600}$ ) after addition of the indicated dilutions of a cloacin DF13 preparation, either untreated $(O)$ or pretreated with membranes of strain W31 $10(\mathrm{pABN} 1)(\triangle)$. In addition, membranes were used which had been preincubated with antiserum raised against whole Iut $A^{+}$bacteria $(\boldsymbol{A})$, or with antiserum absorbed with a membrane preparation of

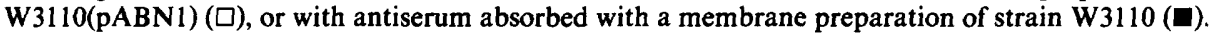

Table 3. Effect of antisera on binding of phage B74K to whole bacteria expressing the aerobactin receptor

Bacterial strain

W3110

W3110

W3110(pLG141)

W3110(pLG141)

W3110(pLG141)

W3110(pLG141)
Antiserum*

Anti-whole cell serum $(1: 2)$

Anti-whole cell serum $(1: 2)$

Anti-whole cell serum $(1: 10)$

Pre-immune serum $(1: 2)$

$$
\begin{gathered}
10^{-3} \times \text { Residual phage titre } † \\
\text { (p.f.u.) }
\end{gathered}
$$

80

94

$9 \cdot 5$

80

68

12

* Bacteria were incubated with antiserum before addition of phage.

† Phage remaining after adsorption with the bacterial strain indicated.

caused no observable diminution of the protective effect (Fig. 3). Strain D551 is insensitive to cloacin DF13 and so the effect of antisera could not be assessed in this way.

To determine the effect of antisera on the binding of phage B74K to the aerobactin receptor, samples of phage lysate were incubated with bacteria expressing the receptor and, after removal of the bacteria, the residual phage titre was determined. Pre-incubation of the bacteria with antiserum against whole Iut $\mathrm{A}^{+}$bacteria diluted 1 in 10 significantly reduced, and diluted 1 in 2 completely abolished measurable binding of phage (Table 3). Pre-incubation of the bacteria with pre-immune serum had virtually no effect. Phage B74K does not form plaques on strain D551 and so the effect of antisera could not be assessed for this strain.

In a further study of competitive binding to IutA, we used a simple plate test to determine the effect of aerobactin on the binding of cloacin DF13 and phage B74K (Fig. 4). Addition of spots of an aerobactin solution to a lawn of W3110(pLG141) significantly reduced the sensitivity of the strain to cloacin DF13 spotted subsequently at the same positions. The sensitivity of W3110(pLG141) to phage B74K, however, was not influenced by the presence of aerobactin.

\section{Effect of antisera on infections of mice with D551}

To assess whether any of the antisera raised against the aerobactin receptor could protect experimentally infected animals, suspensions of strain D551 were incubated with equal volumes of $1: 2$ dilutions of sera at $37^{\circ} \mathrm{C}$ for $45 \mathrm{~min}$ to allow antibody binding before inoculation into 


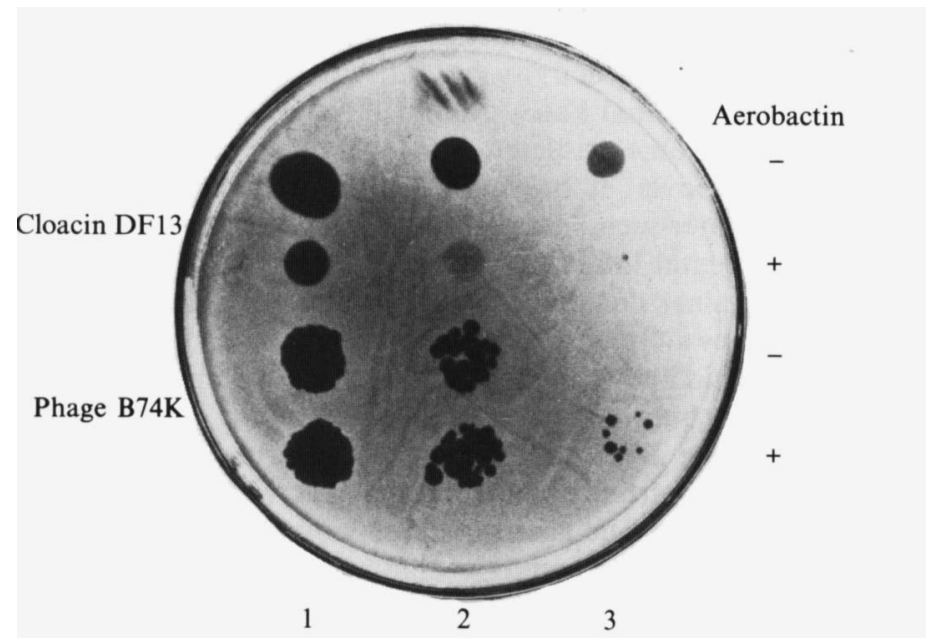

Fig. 4. Effect of aerobactin on the binding of cloacin DF13 and bacteriophage B74K to IutA+ bacteria. Samples of ferric-aerobactin $\left(10 \mu \mathrm{l}\right.$ of a $10 \mu \mathrm{g} \mathrm{ml}^{-1}$ solution) were spotted onto each of three positions $(1-3)$ in each of two rows as indicated $(+)$ on a lawn of strain W3110(pLG141) on nutrient agar, and allowed to dry. Samples $(5 \mu \mathrm{l})$ of cloacin DF13 or phage B74K (1) and of 10-fold (2) and 100-fold (3) dilutions of these preparations were applied in two rows, one coincident with $(+)$ and one away from $(-)$ the aerobactin spots. The plate was incubated overnight at $37^{\circ} \mathrm{C}$.

mice as described above. As expected from the results of the in vitro experiments presented in this paper, we observed no significant protective effect with any of the antisera. Similar numbers of mice died at any given inoculum dose, and with similar rapidity, regardless of pretreatment.

\section{DISCUSSION}

Possession of the aerobactin system by pathogenic bacteria has been implicated as a virulence factor by epidemiological evidence (Montgomerie et al., 1984; Carbonetti et al., 1986; Linggood et al., 1987; Jacobson et al., 1988) and by studies using laboratory strains in experimental infections (Williams, 1979). We believe, however, that this paper contains the first report in which the aerobactin genes alone, isolated from other potential virulence factors encoded, for example, by ColV plasmids, have been studied in the genetic background of a clinical $E$. coli isolate. Nassif \& Sansonetti (1986) showed that cloned aerobactin genes increased the lethality of a relatively avirulent $K$. pneumoniae strain, but they did not compare isogenic pairs of strains, and the virulence of the strain carrying the recombinant plasmid was still lower than that of the strain carrying the entire plasmid from which the aerobactin genes were cloned. The aim of our work was to determine if the aerobactin receptor-protein could be utilized as a protective antigen to produce antibodies for use in immunoprophylactic therapy.

Antibodies raised against the native IutA protein in whole cells reacted with native protein to inhibit binding of aerobactin, cloacin DF13 and phage B74K, and in an ELISA with whole cells. No activity was observed when antisera raised against denatured IutA were used in binding assays and they are therefore unlikely to be effective in immunotherapy. However, both displayed activity for Iut $A$ in denatured form in immunoblot and immunoprecipitation experiments (in which the antiserum raised against whole cells showed no activity), indicating that they may be of use in epidemiological studies to identify the presence of the aerobactin receptor in clinical isolates. These results agree with the observations of others that antisera raised against a protein in denatured form often react poorly or not at all with the native protein, and vice versa (Benjamin et al., 1984; Gabay et al., 1985). The majority of antibodies recognize conformational epitopes in native proteins (Atassi \& Smith, 1978; Benjamin et al., 1984) which depend on the secondary and tertiary structure of the protein and so are normally lost upon denaturation (Benjamin et al., 1984), whereas antibodies raised against denatured proteins recognize sequential epitopes, which may be distorted by secondary structure or buried within 
the native protein and, therefore, not accessible to immunoglobulins. However, there are examples of inhibition of biological activity by antisera raised against denatured proteins; antisera raised against SDS-denatured FhuA protein of $E$. coli blocked adsorption of phage T5 and partially inhibited ferrichrome-mediated iron uptake by the biologically active native protein (Coulton, 1982). Moreover, it has been claimed that antisera raised against SDSdenatured iron-repressible outer-membrane proteins of a virulent $E$. coli strain passively protected turkeys in experimental infections (Bolin \& Jensen, 1987) and similar results were obtained with antibodies against denatured OmpF protein of Pseudomonas aeruginosa in a burned-mouse model (Matthews-Greer \& Gilleland, 1987).

We show here that aerobactin and immunoglobulins block the binding of cloacin DF13, that cloacin DF13 and immunoglobulins reduce aerobactin binding, and that immunoglobulins block the attachment of phage B74K. However, the observations that cloacin DF13 and immunoglobulins in excess only partially block binding of aerobactin, and that aerobactin does not influence phage attachment, argue against the possibility that inhibition is due to direct binding of the competing ligands to a common binding site in the IutA protein. It has been suggested that the majority of binding sites within proteins, including immunoglobulins, are cavities or grooves (Novotny et al., 1987); thus epitopes on the surface of a protein are presumably convex to fit the concave paratopes of immunoglobulins. If this is the case with the aerobactin binding site of IutA it is likely to be non-immunogenic, so that incomplete inhibition of aerobactin-binding is probably due to steric hindrance of access to the binding site by immunoglobulin or cloacin DF13 molecules bound at sites close to it. Alternatively, binding of immunoglobulin or cloacin DF13 to the IutA receptor at sites distant from the siderophore binding site might induce conformational changes within the protein which reduce its affinity for aerobactin, or vice versa.

Although the antiserum raised against whole bacteria had a high degree of activity against native protein expressed on the surface of laboratory strains of $E$. coli, similar activity was not observed against several clinical isolates of $E$. coli. Nevertheless, the degree of aerobactin binding was similar in the clinical isolate D551 and in BZB1022(pABN1), indicating comparable expression of the IutA protein. Thus, either the aerobactin receptor in D551 lacks immunological homology with that encoded by ColV-K30 in the immunizing strain, or it is masked by structures such as LPS which covers about $45 \%$ of the surface area of Gram-negative bacteria (Gmeiner \& Schlect, 1980). While small molecules such as aerobactin (molecular mass 536) would not be significantly inhibited from gaining access to receptors in the outer membrane by LPS, it is likely that large proteins such as cloacin DF13 or immunoglobulin (with molecular masses of 70000 and greater) or phage-adsorption structures would be sterically excluded from the bacterial surface by LPS.

Certainly the presence of O-antigens on E. coli, Klebsiella and Citrobacter cells prevented binding of polyclonal and monoclonal antibodies raised against the E. coli K12 PhoE protein (Van der Ley et al., 1986b), and the binding of phages and colicins to $E$. coli may also be abolished (Van der Ley et al., 1986a). Recently Bently \& Klebba (1988) used a series of $r f a E$ mutants of $E$. coli and Salmonella typhimurium to demonstrate that anti-porin monoclonal antibodies bind more effectively the shorter the LPS side-chain. On the other hand, Griffiths $e t$ al. (1983) showed that the iron-repressible outer-membrane proteins of a smooth $0111 \mathrm{E}$. coli strain were readily labelled by a lactoperoxidase-radioiodination technique, indicating that they were surface-exposed and accessible to at least some large protein molecules. TCA has been used to remove LPS from the surface of Coxiella burnetii cells to expose antigens that are normally shielded (Hackstadt, 1988). When a modification of this extraction procedure was used to treat smooth $E$. coli cells, antiserum raised against whole Iut $\mathrm{A}^{+}$bacteria was able to bind specifically, confirming that the aerobactin receptor protein in these strains is usually masked rather than immunologically different from the protein expressed by the immunizing strain. That this effect is associated with LPS rather than the capsule may be inferred from the observation that antibodies bind to the aerobactin receptor of a rough $\mathrm{K} 1$ strain in an ELISA, but not to smooth $\mathrm{K} 1$ types. It has recently been shown that the presence of LPS encoded by chromosomal genes of Shigella flexneri inhibited binding of cloacin DF13 to the $76 \mathrm{kDa} S$. flexneri aerobactin receptor 
in $E$. coli-S. flexneri hybrid cells (Derbyshire et al., 1989). These results, our own failure to protect mice from challenge with smooth E. coli, and particularly in view of the fact that the Oserogroups most commonly associated with extraintestinal infections all afforded protection of the aerobactin receptor protein from access of immunoglobulins suggest that the prospect of using IutA as the basis of a vaccine for the treatment of extraintestinal infections is not promising. Rather, they serve only to highlight the subtlety of evolutionary pressures which maintain the effectiveness of essential bacterial virulence determinants in the face of environmental insults.

We thank Stephen Parry and Margaret Linggood for advice with antisera preparation and for hospitality in their laboratory. We are also grateful to Frits and Ida Orskov for serotyping strain D551, to Timo Korhonen for providing $E$. coli isolates from human infection, and to Karen Baker for providing antisera against the $E$. coli OmpA protein.

\section{REFERENCES}

Atassi, M. Z. \& SMith, J. A. (1978). A proposal for the nomenclature of antigenic sites in peptides and proteins. Immunochemistry 15, 609-610.

Benjamin, D. C., Berzosky, J. A., East, I. J., Gurd, F. R. N., Hannum, C., Leach, S. J., Margoliash, E., Michael, J. G., Miller, A., Prager, E. M., Reichlin, M., Sercarz, E. E., SMith-Gill, S. J. \& WILsON, A. C. (1984). The antigenic structure of proteins: a reappraisal. Annual Review of Immuno$\log y$ 2, 67-101.

Bently, A. T. \& KlebBa, P. E. (1988). Effect of lipopolysaccharide structure on reactivity of antiporin monoclonal antibodies with the bacterial cell surface. Journal of Bacteriology 170, 1063-1068.

Bindereif, A. \& NeIlandS, J. B. (1983). Cloning of the aerobactin-mediated iron assimilation system of plasmid ColV-K30. Journal of Bacteriology 153, 1111-1113.

Bindereif, A., Braun, V. \& HantKe, K. (1982). The cloacin receptor of ColV-bearing Escherichia coli is part of the $\mathrm{Fe}^{3+}$-aerobactin transport system. Journal of Bacteriology 150, 1472-1475.

BinNs, M. M., Davies, D. L. \& HaRdy, K. G. (1979). Cloned fragments of the plasmid ColV,I-K94 specifying virulence and serum resistance. Nature, London 279, 778-781.

Bolin, C. A. \& Jensen, A. E. (1987). Passive immunization with antibodies against iron-regulated outer membrane proteins protects turkeys from Escherichia coli septicemia. Infection and Immunity 55, 1239-1242.

BraUn, V. (1981). Escherichia coli cells containing the plasmid ColV produce the iron ionophore aerobactin. FEMS Microbiology Letters 11, 225-228.

Carbonetti, N. H. \& Williams, P. H. (1984). A cluster of five genes specifying the aerobactin iron uptake system of plasmid ColV-K30. Infection and Immunity 46, 7-12.

Carbonetti, N. H., Boonchai, S., Parry, S. H., VAISANEN-RHEN, V., KoRHONEN, T. K.\& Williams, P. H. (1986). Aerobactin-mediated iron uptake by Escherichia coli isolates from human extraintestinal infections. Infection and Immunity 51, 966-968.

Clancy, J. \& SAVAGE, D. C. (1981). Another colicine V phenotype: in vitro adhesion of Escherichia coli to mouse intestinal epithelium. Infection and Immunity 32, 343-352.
Cohen, S. N., Chang, A. C. Y. \& Hsu, L. (1972). Nonchromosomal antibiotic resistance in bacteria: genetic transformation of Escherichia coli by R-factor DNA. Proceedings of the National Academy of Sciences of the United States of America 69, 21102114.

COOPER, P. C. \& JAMES, R. (1985). Three immunity types of klebicins which use the cloacin DF13 receptor of Klebsiella pneumoniae. Journal of General Microbiology 131, 2313-2318.

Coulton, J. W. (1982). The ferrichrome-iron receptor of Escherichia coli K-12. Antigenicity of the FhuA protein. Biochimica et biophysica acta 717, 154162.

Derbyshire, P., Baldwin, T., Stevenson, P., Griffiths, E., Roberts, M., Williams, P. H., Hale, T. L. \& Formal, S. B. (1989). Expression in Escherichia coli $\mathrm{K}-12$ of the 76,000 Dalton iron-regulated outer membrane protein of Shigella flexneri confers sensitivity to cloacin DF13 in the absence of Shigella Oantigen. Infection and Immunity (in the Press).

Ford, S., COOPER, R. A. \& Williams, P. H. (1986). Biochemical genetics of aerobactin biosynthesis in Escherichia coli. FEMS Microbiology Letters 36, 281285.

Gabay, J., Schenkman, S., Desaymard, C. \& SCHWARTZ, M. (1985). Monoclonal antibodies and the structure of bacterial membrane proteins. In Monoclonal Antibodies against Bacteria, pp. 249-282. Edited by A. J. L. de Macario \& C. de Macario. New York: Academic Press.

GMEINER, J. \& SCHLECT, S. (1980). Molecular composition of the outer membrane of Escherichia coli and the importance of protein-lipopolysaccharide interaction. Archives of Microbiology 127, 81-86.

de Graaf, F. K., Spanjaerdt Speckman, E. A. \& Stouthamer, A. H. (1969). Mode of action of a bacteriocin produced by Enterobacter cloacae DF13. Antonie van Leeuwenhoek 35, 287-306.

Griffiths, E., Stevenson, P. \& Joyce, P. (1983). Pathogenic Escherichia coli express new outer membrane proteins when growing in vivo. FEMS Microbiology Letters 16, 95-99.

HACKSTADT, T. (1988). Steric hindrance of antibody binding to surface proteins of Coxiella burnetii by phase I lipopolysaccharide. Infection and Immunity 56, 802-807. 
Henriksen, A. Z. \& Maeland, J. A. (1987). The porin protein of the outer membrane of Escherichia coli: reactivity in immunoblotting, antibody-binding by the native protein, and cross-reactivity with other enteric bacteria. Acta pathologica microbiologica et immunologica scandinavica B95, 315-321.

Jacobson, S. H., Tullus, K., Wretlind, B. \& BRAUNER, A. (1988). Aerobactin-mediated uptake of iron by strains of Escherichia coli causing acute pyelonephritis and bacteriaemia. Journal of Infection 16, 147-152.

KESSLER, S. (1975). Rapid isolation of antigen from cells with a staphylococcal protein A-antibody adsorbent: parameters of the interaction of antibody-antigen complexes with protein A. Journal of Immunology 125, 1617-1624.

Korhonen, T. K., Valtonen, M. V., Parkrinen, J., Vaisanen-Rhen, V., Finne, J., Orskov, F., Orskov, I., Svenson, S. B. \& Makela, S. B. (1985). Serotypes, hemolysin production, and receptor recognition of Escherichia coli strains associated with neonatal sepsis and meningitis. Infection and Immunity 48, 486-491.

Krone, W. J. A., Stregehuis, F., Koningstein, G., VAN Doorn, C., RoOsendaAl, B., DE GraAf, F. K. \& OUDEGA, B. (1985). Characterisation of the pColV-K30 encoded cloacin DF13/aerobactin outer membrane receptor protein of Escherichia coli; isolation and purification of the protein and analysis of its nucleotide sequence and primary structure. FEMS Microbiology Letters 26, 153-161.

LINGGOOd, M. A., Roberts, M., Ford, S., PARRY, S. H. \& Williams, P. H. (1987). Incidence of the aero-bactin iron uptake system among Escherichia coli isolates from infections of farm animals. Journal of General Microbiology 133, 835-842.

Martinez, J. L., Cercenado, E., Baquero, F., Perez-Diaz, J. C. \& Delgado-Iribarren, A. (1987). Incidence of aerobactin production in Gramnegative hospital isolates. FEMS Microbiology Letters 43, 351-353.

Matthews-Greer, J. M. \& Gilleland, H. E. (1987). Outer membrane protein $\mathrm{F}$ (porin) preparation of Pseudomonas aeruginosa as a protective vaccine against heterologous immunotype strains in a burned mouse model. Journal of Infectious Diseases 155, 1282-1291.

Montgomerie, J. Z., Bindereif, A., Neilands, J. B., Kalmanson, G. M. \& Guze, L. B. (1984). Association of hydroxamate siderophore (aerobactin) with Escherichia coli isolated from patients with bacteremia. Infection and Immunity 46, 835-838.

NASSIF, X. \& SANSONETTI, P. J. (1986). Correlation of the virulence of Klebsiella pneumoniae $\mathrm{K} 1$ and $\mathrm{K} 2$ with the presence of a plasmid encoding aerobactin. Infection and Immunity 54, 603-608.

Novotny, J., HaNdschumacher, M. \& Bruccoleri, R. E. (1987). Protein antigenicity: a static surface property. Immunology Today 8, 26-31.

O'BRIEN, I. G. \& GiBSON, F. (1970). The structure of enterochelin and related 2,3-dihydroxy- $N$-benzoylserine conjugates from Escherichia coli. Biochimica et biophysica acta 215, 393-402.
Perry, R. D. \& San Clemente, C. L. (1979). Siderophore synthesis in Klebsiella pnoumoniae and Shigella sonnei during iron deficiency. Journal of Bacteriology 140, 1129-1132.

Pollock, J. R. \& NeIlands, J. B. (1970). Enterobactin, an iron transport compound from Salmonella typhimurium. Biochemical and Biophysical Research Communications 38, 989-992.

Pugsley, A. P. (1985). Escherichia coli K12 strains for use in the identification and characterization of colicins. Journal of General Microbiology 131, 369376.

Roberts, R. B., Abelson, P. H., Cowie, D. B., Bolton, E. T. \& Britten, R. J. (1963). Studies of biosynthesis in Escherichia coli. Publication no. 607, Carnegie Institute of Washington, Washington, DC.

Roberts, M., LeavitT, R. W., Carbonetti, N. H., FORD, S., COOPER, R. A. \& Williams, P. H. (1986a). RNA-DNA hybridization analysis of transcription of the plasmid ColV-K30 aerobactin gene cluster. Journal of Bacteriology 167, 467-472.

Roberts, M., Partha Sarathy, S., Lam-Po-Tang, M. K. L. \& WiLliams, P. H. (1986b). The aerobactin iron uptake system in enteropathogenic Escherichia coli: evidence for an extinct transposon. FEMS Microbiology Letters 37, 215-219.

Sokol, P. A. \& Woods, D. E. (1984). Antibody inhibition of ferripyochelin binding to Pseudomonas aeruginosa cell envelopes. Biochemistry 23, 50765080.

Sokol, P. A. \& Woods, D. E. (1986). Monoclonal antibodies to Pseudomonas aeruginosa ferripyochelin-binding protein. Infection and Immunity 53, 621627.

Towbin, H., Staehelin, T. \& Gordon, J. (1979). Electrophoretic transfer of proteins from polyacrylamide gels to nitrocellulose sheets: procedure and some applications. Proceedings of the National Academy of Sciences of the United States of America 76, 4350-4354.

VÄISÄNEN-RHEN, V., Elo, J., VaISANEN, E., SiItonen, A., Orskov, I., Orskov, F., Svenson, S. B., MakelA, P. H. \& Korhonen, T. K. (1984). PFimbriated clones among uropathogenic Escherichia coli strains. Infection and Immunity 43, 149-155.

VAN der Ley, P., de GraAfF, P. \& Tommassen, J. (1986). Shielding of Escherichia coli outer membrane proteins as receptors for bacteriophages and colicins by $\mathrm{O}$-antigenic chains of lipopolysaccharide. Journal of Bacteriology 168, 449-451.

VAN DeR Ley, P., Kuipers, O., Tommassen, J. \& LUGTENBERG, B. (1986). O-Antigenic chains of lipopolysaccharide prevent binding of antibody molecules to an outer membrane pore protein in Enterobacteriaceae. Microbial Pathogenesis 1, 43-49.

W ARner, P. J., Williams, P. H., Bindereif, A. \& NeIlands, J. B. (1981). ColV plasmid-specified aerobactin synthesis by invasive strains of Escherichia coli. Infection and Immunity 33, 540-545.

Williams, P. H. (1979). Novel iron uptake system specified by ColV plasmids: an important component in the virulence of invasive strains of Escherichia coli. Infection and Immunity 26, 925-932. 